\title{
Strange Bedfellows
}

The Politics of Late-Night

Television Comedy

Russell Peterson

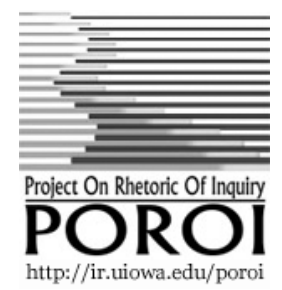

Poroi, 5, 1, September, 2008

Q: If George W. Bush, J ohn Kerry, and

Ralph Nader were all in a rowboat in

the middle of the ocean, and the

boat tipped over, who would be saved?

\section{A: The United States.}

1 This riddle's shelf-life would appear to have run out on November 1 , 2004. But in fact, it is a perennial - or more accurately, a quadrennial. When I first heard it in 1980, the three men in a boat were J immy Carter, Ronald Reagan, and J ohn Anderson. Conceivably it was told about Nixon, Humphrey, and Wallace in 1968; and it will probably reappear in 2008 with a new set of sailors. An example of "jokelore," its origins are mysterious. I heard it from my father, who heard it from my uncle, who heard it from a coworker, who heard it from who knows whom. It is one of those anonymous witticisms that are tossed around the break room, handed around the water cooler, and, in more recent times, distributed by e-mail.

2 For the past thirty-some years, however, America's most fertile source of political jokes has been quite identifiable: the late-night television monologue. The formula perfected by J ohnny Carson and still practiced nightly by the likes of J ay Leno, David Letterman, and Conan O'Brien adds a temporal specificity and ad hominem edge best demonstrated by applying it to the 2004 version of the rowboat riddle. Although the set-up would remain the same, the answer would more likely be:

All of them! Bush would be pulled out by his father's friends, who had followed close behind, on an oil tanker. Kerry would pull Nader out, and spend the next thirty-five years reminding everyone of his heroism. And Nader would sue the boat's manufacturer, claiming it is "unsafe at any speed." 
This essay explores late-night political humor's particular methods and motives. But the first important point is that the riddle's political valence survives the translation. In both the original and the "Leno-ized" form, it is more anti-political than political. It is a cynical attack aimed at the whole notion of political leaders' competence more than a criticism of any particular candidate or set of candidates.

3 The timeless nature of the generic version makes this subtext obvious: the 2004 version is the same as the 1980 version, save for the names. Yet the late-night version is nearly as adaptable. The particularizing details attached to each candidate (in every election) are intended, not to illuminate differences, but to cancel each other out. Through balanced repetition, distinctions among politicians become as meaningless as the colored shells of M\&M candies: underneath it all, they are all the same.

4 Post-election analyses tend to examine the voting behavior of such identifiable blocs as Hispanics, the young, the elderly, "moral values" voters, and "security moms." Arguably though, the pivotal (not to say "decisive") demographic group is the non-voting bloc. Many who eschew the opportunity to exercise the franchise insist that all politicians are alike and all elections pointless. (Many more suspect this but vote anyway.) This phenomenon is usually described as apathy, but mere apathy does not explain the charge implicit in the boat riddle. Not caring is no motivation for laughter; hostility is. Effective tendentious jokes tap into deeply held, if unspoken, convictions. In this case, the apparent conviction is that all politicians are created not only equal, but equally evil.

5 American distrust and hostility toward politics are wellestablished. A Necessary Evil by Garry Wills provides a particularly thorough historical overview of these attitudes. ${ }^{1}$ Nor am I the first to point out the anti-political nature of much of American political humor. Still I am not as sanguine as earlier observers about what I see. Charles Schutz wrote approvingly of the "positive negativity" of anti-political humor, while Louis Rubin celebrated as "the Great American J oke" satire aimed at exposing the hopeless gap between America's democratic ideals and its political realities. ${ }^{2}$ Both believed anti-political humor could play a democratically constructive role.

6 There is a tradition of critically engaged political humor in America. Although some has attacked particular persons, parties, 
or ideologies, much has been broadly anti-political. It has expressed a timeless and fundamental contempt for the whole governmental process. Many of Mark Twain's satirical forays and many of H. L. Mencken's sardonic invectives exemplify this approach.

7 Whether the aim is sharpshooter precise or blunderbuss broad, satire - by which I mean wit that is sincerely critical rather than merely dismissive - has always been a minority strain in American political humor. Certainly it is no word for the comedy that J ay Leno, David Letterman, and Conan O'Brien bring to American television viewers night after night. These comedians traffic in humor that is not just anti-political but also pseudo-satirical. For one thing, their nightly assaults on political leaders are carefully "balanced" to avoid the appearance of partisan preference. For another, they avoid any critical engagement with (or against) politics. Instead they favor of a cheerful kind of lazy nihilism. The political satirist points an accusing finger at those he judges to be corrupt, incompetent, or wrong; the anti-political satirist shakes his fist at the powerful, whomever they may be; the pseudo-satirist merely shrugs. The late-night comedians' motto is: we make fun of everybody, and we don't mean any of it.

\section{Stand-up Guys}

8 Twain once wrote that "Humor must not professedly teach and it must not professedly preach, but it must do both if it would live forever. And by forever, I mean thirty years."3 Well, J ohnny Carson hosted The Tonight Show for 30 years; and although the thousands of monologues he delivered and tens of thousands of individual jokes he told during those thirty years were individually as short-lived as mayflies, the style, the (anti)political attitude, and the collective gist of those jokes has endured even beyond his tenure. Topical comedy a la Carson has not only comprised the mainstream of televised political comedy, it has permeated other parts of our political discussion. Political cartoonists, who were once characteristically earnest and partisan are now mostly opportunistic, topical jokers: pictorial Lenos. Broadcast and print pundits regularly invoke, reinforce, even occasionally originate the personalized comic tropes that have become staples of late-night humor. ${ }^{4}$

9 Political humor in the late-night style is not a countercurrent to the status-quo flow but part of it. George Orwell once wrote that "every joke is a tiny revolution." 5 That characterization, along with 
the corollary that comedians are rebels or iconoclasts, is simplistic at best. In the case of late-night comedy, it is wrong by 180 degrees.

10 Stand-up comics, particularly those aiming to maintain a viable network audience, are consensus seekers more than they are rabble rousers. They don't succeed through provocation, or by saying things with which a substantial portion of their audience is likely to disagree. Their preferred method is to lead the audience down a short, circuitous, potentially provocative path - only to surprise it in the end by telling it something it already "knows" but might not expect in that particular form. Stand-up is like a magician's trick, minus the magic. The audience is set up to expect something: for example, by the introduction of the Ace of Spades, say, Bill Clinton. Then it is momentarily diverted from the fulfillment of that expectation through misdirection. This is a matter of the comic's or the conjurer's technique. The difference is in the denouement. The magician mystifies: How did that card get to the top of the deck? The comedian confirms: Yep, that Clinton is one horny dude! It is one thing to foil people's expectations regarding the emptiness of top hats or the ability of the human body to survive sawing in half. It is another to challenge conventional political wisdom. While empty hats induce wonder, such unsettled beliefs provoke anger, fear, defensiveness, discomfort. People who are uncomfortable tend not to laugh.

11 Nor are the comedian's tricks all done with mirrors. Although he does reflect audience beliefs, the comedian must first reach below the surface of social decorum (or political piety) to expose those beliefs. The comedian's license is not to challenge what his audience is thinking, but to say it out loud.

12 In Stand-up Comedy in Theory, J ohn Limon argues that "what is stood up in stand-up comedy is abjection." Thus he adapts J ulia Kristeva's sense of "abjection" to refer to "a psychic worrying of those aspects of oneself that one cannot be rid of, that seem, but are not quite, alienable - for example, blood, urine, feces, nails, and the corpse ... some skin that cannot be sloughed."6 Limon's argument allows him to explore ways in which specific comedians "stand-up" a full range of discomfitting topics for audience consideration: from bodily functions to their own unspoken prejudices. With this persuasive (if somewhat elusive) argument in mind, we might revise the notion that the comedian seeks consensus. We might say instead that he seeks to uncover it. Indeed some of the most pleasurable laughs delivered by stand-up 
comedy arise from unearthing unexpected areas of agreement: "I didn't know other people were thinking that, too!"

13 Even though the comedian is obliged to find ways to tell the audience what it already believes, that does not make him the subservient party in the relationship. Stand-up comedy, apart from the occasional heckler (which is not something TV comics usually face) is a one-way conversation. David Marc writes of the "totalitarian imagery" of stand-up. Outfitted with a microphone and a spotlight, a lone figure stands above a crowd: lecturing them, manipulating them, and feeding off their responses. ${ }^{7}$ As power trips go, controlling the laughter of a crowd is hard to beat, as any comedian will tell you who has ever had a good night. But a comedian is not a dictator. It is impossible to bully people into genuine laughter, and few comedians could afford to employ goon squads anyway to keep the rabble in line.

14 The comedian is both "above" the crowd and beholden to it. But he also must be one with it. Stand-up's iconography may be totalitarian, but its essence is populist. As Bernard Timberg says, the comedian is neither the audience's slave nor its master but its representative. ${ }^{8}$ This is particularly true for the comedian who hosts a nightly network show.

15 In an insightful analysis of J ohnny Carson's appeal, Timberg describes him as "straddling the worlds of common sense and show business." 9 The late-night host is something of a double agent: he can go toe-to-toe with the elite denizens of Hollywood or Washington, DC; yet he is also "one of us," a civilian, a commoner. "Though clearly a star receiving celebrity treatment, he does not place himself above the audience nor beneath them as a fool or comic butt of jokes," writes Timberg. "As Everyman, Carson suggests he is directly on beam with the sensibilities of his viewing public." 10

16 Still, though he may be an Everyman, he can't be just Anyman. If the late-night hosts resemble elected representatives, a cursory glance reveals that they cover only as wide a spectrum of American diversity as our presidential candidates. Carson and his network heirs are all white, male, and non-J ewish. This last is a noteworthy characteristic, given the disproportionate number of stand-up comics who are J ewish: from Carson contemporaries like Lenny Bruce and Mort Sahl to Leno-generation stalwarts such as J erry Seinfeld, Richard Lewis, Garry Shandling (who once shared permanent guest-host status with Leno), and J on Stewart (on 
whom the broadcast networks passed more than once before he found success on cable).

17 Taking into account such interesting though short-lived exceptions as J oey Bishop, Arsenio Hall, and J oan Rivers, the normative straight, white, goyische male-ness of late-night hosts is part of a story familiar to historians of television in particular and American popular culture in general. It is a story of exclusion and excuses: our southern affiliates will never go for this; she's funny, but she's not "relatable;" he makes our advertisers nervous. This is perhaps an appropriate point to explain that I use the pronoun "he" throughout, not from insensitivity, but to acknowledge the salient fact that late-night has remained a white-male bastion. Television may have finally discovered the commercial benefits of diversity in prime time, and Oprah Winfrey may have become the most successful talk-show host of all time. Nonetheless the ability to operate from a narrowly normative base may remain a particularly important prerequisite for the late-night host.

18 Dave and J ay, and J ohnny before them, are all - in show-biz lingo - "personalities." In another, crucial sense, however, they are better described as non-personalities. Offstage, Carson was known for being unknowable. Kenneth Tynan compared him to "an elaborately wired security system."11 J ournalistic accounts invariably termed him "aloof" or "intensely private." Letterman seems to be practically a hermit: he will now admit to having a son, but he has rarely mentioned the child's mother on the air by name - none of our business, apparently. Leno does not seem as aloof, but he's a manic workaholic who doesn't seem to have much of an off-stage life either.

19 Timberg and a number of journalists who have written about Carson describe him as a descendent of the Yankee characters who appeared in joke books and on the 19th-century stage. Indeed Constance Rourke's American Humor description of this icon fits his television descendant pretty well. The Yankee is a variant of the "wise fool." His regional origins are less important than his character. A country bumpkin, he never fails to get the better of his more "sophisticated" foils. Thus did the Iowa-born, Nebraskabred Carson show up the Washington politicians who appeared in his monologue and the Hollywood sophisticates who sat on his couch. But the most interesting connection, something that Rourke emphasizes as one of the Yankee's defining features, is that he always maintains his "blank countenance."12 Even when you can tell he is kidding about something, it is impossible to tell how 
he really feels about it.

20 Carson and his late-night heirs are not deadpan comics on the order of Steven Wright. Still their blankness - their dry understatement, their unethnic whiteness, their apparent lack of lives outside of their shows - allows them the latitude to embody the contradictions demanded by their role. The late-night host is an insider and an outsider. He is an everyman celebrity and a nonpartisan, nonpolitical political commentator. What J ohnny Carson often said in reference to his private political beliefs could apply equally well to his ethnic background and his personal identity: "No one knows what I am."

\section{Both Sides Now}

21 The hosts' rationale for maintaining a politically disinterested pose is fairly obvious. As J ay Leno puts it, as soon as you declare your support for one party or the other, "you've lost half the crowd already."13 Although numbers compiled by the Center for Media and Public Affairs show that the jokes about Republicans and Democrats are not in perfect balance from month to month, the hosts plainly make a conscious effort to say nearly as many disparaging things about one party or candidate as the other.

22 In this, the late-night comics follow the paradigm of journalistic "objectivity," which is more accurately described as "evenhandedness." It works like this: if candidate A lied about the weapons of mass destruction, the missile gap, or what-have-you, we'd better find a way to say that candidate B hasn't been completely forthcoming either, even if he only lied about how much he pays for his haircuts. Of course, politicians and political operatives understand these rules and know how to exploit them to maximum advantage. Whenever "answers" are a matter of political argument, the journalist is obliged to report what the flacks on each side say, while drawing no conclusions about who, if anybody, is right. Conflicting evaluations are thus presented to the viewers in the manner of a multiple-choice question: "Two plus two? Democrats say the answer is three. Republicans insist it is five." Every debatable issue ends in a stalemate of dueling claims, and every story ends with an ellipsis: "Whatever the sum eventually agreed, one thing remains certain: this dispute will not be resolved any time soon."

23 The "Leno-ized" version of the boat riddle is a comedic illustration of this principle: it is evenhanded, because it says something bad 
about all three candidates. In monologues, the usual balance is achieved cumulatively, over the course of several jokes. Yet the comedic version of "objectivity" is more satisfying than the journalistic variety in one respect. Current journalistic practice dictates that facts (and increasingly, alleged facts) be presented with an eye toward "balance" (as if every politically troublesome truth has an equal and opposite countertruth), but without rendering the judgment that comedy punches home.

24 J ournalistic evaluation can only go so far. Reporters are allowed to gather facts, and to place these facts - or "factors," metaphorically - into something resembling an equation. At this point, though, they are supposed to get out of the way and let us do the math. A reporter may, for instance, present evidence of some presidential misdeed: the Nixon tapes, the George H. W. Bush participation in the arms-for-hostages deals of the Iran-Contra Affair, the stained dress of Monica Lewinsky. Then the reporter must add the president's denials: "I am not a crook." "There was no quid pro quo." "I did not have sexual relations with that woman!" But the reporter may not conclude bluntly that the president is lying. The news may put two and two together on one side of what may be implied to be an equation; but the other side of the equals sign must, deliberately, stay blank.

25 The calculus of journalism, in its scrupulous pursuit of Objective Truth, often delivers only frustrating uncertainties. And while there is undoubtedly much to be said for caution and objectivity, these offer the audience little in the way of catharsis. Comedy, on the other hand, revels in judgment and trades in catharsis. Consider this J ay Leno joke, which aired two weeks after the 2001 World Trade Center attack:

I'm watching our local news, and they said, "America continues to search for alleged terrorist Osama Bin Laden." Alleged? We already said we want him "Dead or Alive." Do we have to keep saying "alleged?" Apparently it's okay if we kill him, [but] God forbid he sues us for libel. ${ }^{14}$

This joke neatly summarizes what many readers and viewers find frustrating about "the news." J ournalists are supposed to tell us only what they know to be true then leave the rest open-ended: here are the confirmed facts, here are some possible interpretations, here's what might happen next. Comedy can throw caution and propriety aside to tell us what we know (or 
believe) to be true. Where journalism deals only in allegations, comedy indicts and convicts. In the court of comedy, Tricky Dick, Ollie North, Slick Willy, Osama, and O.J . are all, in the immortal words of Doonesbury's Mark Slackmeyer, "Guilty, guilty, guilty!” This may or may not be fair, but it is satisfying.

26 Even if the late-night comics may eschew "fairness," they must still respect "balance." The late-night monologist must render judgments - since every punchline is, in some sense, a verdict. But he may not "take sides," because he cannot afford to lose half his audience. This might present an insoluble dilemma, but for one thing: in the court of late-night comedy, every politician is "guilty, guilty, guilty."

\section{Abe's Faves}

27 The late-night ethos of equal-opportunity offender mimics the journalistic model of objectivity and stems from the commercial nature of television: even worse than the prospect of losing half the audience is losing half the sponsors. Yet the American penchant for anti-political political humor has historical roots as well. Two of the most popular comic writers of the Civil War era were Artemus Ward and Petroleum V. Nasby. Both were great favorites of Abraham Lincoln. On the day Lincoln presented the first draft of the Emancipation Proclamation to his cabinet, he first broke the ice by reading from Ward's "High-Handed Outrage at Uticky." He used a volume the author had personally sent the President. ${ }^{15}$ Regarding The Nasby Papers, the President once confided to Senator Charles Sumner, "For the genius to write these things I would gladly give up my office."16

28 Nasby (a.k.a. David Ross Locke) and Ward (a.k.a. Charles Farrar Browne) each adopted the guise of an uneducated semi-rube. They used slang and comic misspellings to indicate their alteregos' unlettered naiveté. Each supplemented his literary efforts on the lecture circuit, taking as his principal subject matter the political personalities and issues of the day. Beyond these similarities, however, Nasby and Ward diverged sharply in their methods and goals.

29 David Ross Locke, in the words of J ames C. Austin, "was a satirist - not a humorist."17 Locke was a reformist, though not a radical, Republican. He crusaded for women's rights and for temperance. Above all, he was an unabashed opponent of slavery who had aided runaways in the early days of the Civil War. Nasby, his alter ego, 
was a "Copperhead" (i.e., a Northern Confederate sympathizer). Locke made Nasby a mouthpiece for opinions he despised, the better to expose their illogic and immorality.

30 There was no room for empathy in Locke's impersonation. Consider the bitter opening of "The Assassination" (1865). It is shocking, even at the remove of almost a century and a half:

The nashen mourns! The hand uv the vile assassin hez bin raised agin the Goril - the head of the nashen, and the people's Father hez fallen beneath the hand uv a patr - vile assassin .... .

No man in Noo J ersy laments his untimely death more than the undersined. I commenst weepin perfoosely the minit I diskivered a squad uv returned soljers comin round the corner, who wuz a forcin constooshnel Dimekrats to hang out mournin. ${ }^{18}$

In the true satirical spirit, Locke took his comic work seriously. "If there is an American who reads these pages and does not from this time out make politics as much a part of his business as planting his crops, that American does not know what is good for him," declared Locke in the foreword to his 1882 collection Nasby in Exile. "Government is the most important matter on this earth."19

31 In contrast to the earnest Locke, says Austin, Charles F. Browne "is often spoken of as a 'pure humorist,' in contrast to those comic writers who have an axe to grind." In other words, he was a humorist, not a satirist. ${ }^{20}$ The voice that Browne created for Artemus Ward provided a stylistic template for Petroleum V. Nasby, a debt Locke graciously acknowledged. But Browne did not present Ward as a negative exemplar. In fact, Browne identified so closely with his alter ego that he often signed personal letters with his pen name, and was called Artemus even by some of his close friends. Browne's identification with his character was not unlike the relationship between the "real" J ohnny Carson and the host of The Tonight Show, whereas Locke's relationship to Nasby is analogous to the relationship between Carson and his negative exemplar character Floyd R. Turbo, whose editorial rebuttals were as close to genuine satire as Carson ever allowed himself to come.21

32 Like Carson and his late-night heirs, Artemus Ward was quick to profess his own neutrality. "I hav [ sic] no politics. Nary a one," he 
once wrote. "Showmen is devoid of politics."22 And like the latenight hosts, any "off-stage" politics for Browne are difficult to discern. Though he supported the Union once war broke out, he was skeptical of the abolitionists, and of reformers generally. "He laughed at the excesses on every side," as Austin puts it. ${ }^{23} \mathrm{~J}$ ay Leno boasted cheerfully of contributing jokes to both the Clinton and Dole campaigns in 1996, but Ward's equanimity was broader still. He supported Stephen A. Douglas in the election of 1860, following the lead of his Cleveland Plain Dealer bosses, until war broke out. After that, he supported Lincoln and the Union cause, gently mocking the "seceshers." Yet after the war, he organized and performed at a benefit for the wife of the imprisoned J efferson Davis. Though his sympathetic gesture towards the First Lady of the Confederacy brought considerable public criticism, Browne did not seem to consider his participation a "political" act. ${ }^{24}$

33 That he "hed no politics" beyond a rather vague patriotism is apparent when one compares two of his wartime "interviews." Here is Ward "interviewing" President-elect Lincoln in 1860:

"How kin I ever repay you, Mr Ward, for your kindness?" sed Old Abe, advancin and shakin me warmly by the hand, "How kin I repay you, sir?"

"By givin the whole country a good, sound administration. By poerin ile upon the troubled waturs, North and South. By pursooin a patriotic, firm, and just course, and then, if any State wants to secede, let 'em Sesesh!"25

Visiting J efferson Davis (who affords Ward a "quite perlite" reception) after the conflict has begun, Ward is careful not to be too harsh:

'J . Davis, there's your grate mistaik. Many of us was your sincere frends, and thought certin parties amung us was fussin about you and meddlin with your consarns intirely too much. But J. Davis, the minit you fire a gun at the piece of dry-goods called the StarSpangled banner, the North gits up and rises en massy, in defence of that banner. Not agin you as individooals - not agin the South even - but to save the flag." 26 
Ward demonstrates the same kind of apolitical, "just-kidding" harmlessness that allows Leno and Letterman to joke about Politician A and Politician B without appearing to be for or against either one. That it is "all in fun" is confirmed when both are welcomed, after months or years of nightly mockery, as the shows' guests.

34 By contrast, Nasby would not have cozied up to Lincoln any more than Locke would have embraced Mrs. Davis. The crucial difference between Ward and Nasby, between the pseudo and genuine satirist, is not a matter of ideology but of conviction. In addition to his comic work as Nasby, Locke was prolific as a "serious" writer and lecturer. Whether speaking as Nasby or as himself, though, Locke was always the rhetorician: trying to advance a particular point of view. Browne, like "Artemus Ward," was a showman: he hed no politics. Thus the two might be regarded as representing the divergence of satire and pseudosatire. Nasby is an ancestor to Garry Trudeau and (arguably) J on Stewart; Artemus Ward is the nineteenth-century equivalent of Carson, Leno, Letterman, and O’Brien.

\section{The Personal, the Political, and the Laughable}

35 "The personal is political" is a familiar slogan that arose from second-wave feminism in the 1970s. But it could just as aptly serve as the slogan for late-night political comedy, where the overwhelming majority of punchlines target personalities rather than issues or ideologies. As the so-called "character issue" has become more central to political discussion, the pitch, as it were, has drifted right into the comedians' wheelhouse. For the comic is, and has always been, personal.

36 But this is true only in a narrow, specific sense. What passes for "the personal" in comedy is not true human character, but a social cartoon. The caricatures of politicians in late-night jokes are not sufficiently complex to do justice even to so allegedly uncomplicated a figure as George W. Bush. To the extent that comedy's focus on personalities can influence in turn the wider political discourse, the flattening of complex persons into twodimensional cartoons is probably its most profound effect.

37 Henri Bergson provided a good explanation of comedy's impersonal attention to persons. He observed, to begin with, that sympathy and laughter cannot coexist for the same object in the 
same moment. To laugh at another's misfortune or pain, we may experience a "momentary anesthesia of the heart," forgetting - for that crucial, comic instant - the likely inclination to empathize with another human being. ${ }^{27}$

38 To trip this switch, comedy tricks us into momentarily perceiving the target of laughter as not human. Comedy makes the object of laughter into exactly that: an "object." In Bergson's formulation, human beings become laughable (or laugh-at-able) only when they lose their organic, vital flexibility: only when they become, in effect, more thing than being. Physical comedy provides especially clear illustrations of this principle: an acrobatic leap into the absurd allows us to laugh at Buster Keaton turned into a rolling boulder, Oliver Hardy into a human cannonball, or even Wile E. Coyote into an accordion - without our necessarily being sadistic. Bergson's juxtaposition of mechanical rigidity against what he called élan vital accounts for other kinds of inflexibility: the ideé fixee, the doctrinaire stubbornness of the ideologue. That can perform a similar "dehumanizing" in the service of rendering a fellow-being laughable.

39 Bergson went on to observe that comic characters also tend to be two-dimensional "types" rather than recognizably complex individuals. This can perform a more subtle translation of beinginto-thing than Coyote-into-accordion, although the same principle applies. Tragic heroes, by contrast, are fully human because they are highly particularized. We have to know them well enough to care about them, almost as if they are our acquaintances in flesh and blood. As Bergson points out, "Nothing could be more unique than the character of Hamlet. Though he may resemble other men in some respects, it is clearly not on that account that he interests us most. But he is universally accepted and regarded as a living character. In this sense only is he universally true."28 We come to know Hamlet only over the course of the play; comic characters' universality is of a different order. We recognize the types represented by Harlequin, Falstaff, or Chaplin's Tramp almost from the moment we lay eyes on them. The distinction is apparent, Bergson noted, even in the manner in which tragic and comic characters are referenced: 'We say 'a Tartuffe,' but we should never say 'a Phedre,"' or presumably, "a Hamlet."29 Tragedy is intimate and specific; comedy is public and general, its truths widely applicable.

40 Of course, the politicians who are the butts of late-night comics' jokes are real, living, fully dimensioned individuals. But the 
people in the jokes, though they have the same names, are impostors. They are caricatured, mechanized, android versions of the real things. They are defined with a reductive handful of perfectly consistent traits. Each is as reliably quantifiable as a mathematical constant: Bill Clinton = horny hillbilly, Bob Dole = cranky geezer, etc. These characterizations are more specifically tailored than Bergson would suggest: Bob Dole is not just a Bob Dole, George W. Bush is not merely "dumb" in precisely the same way as Dan Quayle, and Democratic party-boys Bill Clinton and Ted Kennedy are not exactly interchangeable.

41 The reductive logic of comic typing comes into play nonetheless. Veteran Letterman writer Gerard Mulligan explained to the New York Times Magazine's Marshall Sella that this method "goes back to Aristophanes, the pure interplay of streamlined comic attributes: The Phlegmatic Man, the Choleric Man, the Melancholic. Most comedy is based on reducing somebody to one or two basic characteristics and ignoring the rest," Mulligan says. "We're not trying to catch complexities."30 In fact, the late-night comedians aim to obliterate complications: their reductive, "flattening" approach to personality is a comic prerequisite. It is also central to the question of late-night comedy's influence on larger political discourses.

\section{Film at 11:00, J okes at 11:30}

42 Most public speculation about late-night's influence centers on a notion I call the "usurper premise." During the past few election cycles, surveys conducted by the Pew Research Center for the People and the Press have suggested that a sizable percentage of Americans - in the 2004 poll, $28 \%$ of all viewers and $61 \%$ of those under the age of 30 - get some of their political news from latenight comedy shows. Every time this survey is repeated, it creates a flurry of stories in the media, which almost invariably take these findings as proof that the American public is looking for news in all the wrong places. The usurper interpretation suggests that the fourth-estate role which rightfully belongs to the "serious" journalistic establishment is gradually being eclipsed by the creeping ha-gemony of J ay, Dave, Conan and The Daily Show. Topical comedy, in this scenario, is seen descending like an iron curtain over territory once held under the sober sway of Rather, Brokaw, J ennings, the Times, and the Associated Press.

43 In fact, the data fail to support this interpretation. There is no indication that viewers of The Tonight Show and the network news 
comprise mutually exclusive groups. For that matter, C-SPAN ranks higher than late-night in the Pew poll as an alternative source of news, but there have been no articles to date decrying Booknotes TV as a corruption of the body politic. Still the usurper premise is attractive to journalists in that it lets them to apply the ethical standards of their own profession to comedians and then scold the comedians for failing to measure up. This is essentially what Crossfire's Tucker Carlson notoriously did to J on Stewart when Carlson took Stewart to task for his failure to grill J ohn Kerry during his guest appearance on The Daily Show.

44 Perhaps the most thorough and highest-profile airing of the usurper premise appeared two months before the 2000 presidential election in the New York Times Magazine. Heralded by a cover photo of J ay Leno mugging it up with campaign buttons over his eyes and the headline "The Most Trusted Source for Campaign News (well, almost)," Marshall Sella's article cites the Pew survey to once more invoke the specter of comedians preempting the functions of legitimate journalism. Sella even offers readers an exemplar of young citizenship seduced: "Alexis Boehmler is a junior studying English at Davidson College," Sella begins. "At 20, she is bright and well versed, with strong views on the abortion issue and other political matters." But to Sella's dismay, this paragon turns out to be all too typical of a new generation of voters who prefer jokes to journalism. "Her opinions do not betray a hint of apathy or intellectual lethargy, and she has every intention of voting in November. And her primary news source - often, her only news source - is The Daily Show With J on Stewart, a parody. 'T've always gotten news through watching comedy shows,' Boehmler says. 'The coverage on $\mathrm{CNN}$ is something I honestly find boring. . . . With Leno and Stewart, I can get the news in an interesting format."'31 If Boehmler's youthful insolence is not sufficiently shocking, Sella goes on to quote CNN's Wolf Blitzer. His own daughter tells Blitzer that she will vote for Gore - not because of what she has learned of his policies and background from the campaign coverage provided by Daddy's employer (which was no doubt fair, thorough, and untainted by bias or humor), but because "He was cool on The Tonight Show."32

45 The comedians, for their part, are quick to refute the notion that what they do comprises a suitable alternative to The News. "Anybody learning anything from my show would disturb me," Conan O'Brien told the New York Times when asked to comment upon the 1996 edition of the Pew survey. In fact, hejoked, if there 
was any truth to the notion that the public was turning to shows like his for information or political insight, "I would worry grievously for America's future."33

46 Such reflexive denials are, of course, part of the operative ethos of late-night comedians: "these are just jokes, folks." What really riles Sella, beyond the notion that the comedians are trespassing on his tribe's turf, is that they are doing so without paying sufficient obeisance to the great god, Objectivity. "To put it mildly," he sniffs, writers for topical comedy shows "are not traditionally right-wingers." 34 He characterizes the comedic framework for the 2000 Gore/ Bush contest - quite plausibly - as "the stiff guy vs. the dumb guy." But Sella complains that these characterizations are not balanced and that "dumb" is the more damning. (Plainly he is unfamiliar with Richard Hofstadter's AntiIntellectualism in American Life. ${ }^{35}$ ) What's more, he insists, these personalized tropes "don't select themselves," but are "judgment calls - the result of a given staff's political disposition."36

47 Leave aside the question of whether Sella has heard of American anti-intellectualism. His insinuation of a vast, left-wing, comedic conspiracy is unconvincing. Laughter is most often an involuntary response, incompatible with brainwashing. Moreover late-night comedy is a volume business, not a bully pulpit: ten minutes of monologue is too short a span to both entertain people and indoctrinate them. Late-night's reductive approach and repetitive nature undoubtedly help fix personal traits for individual politicians in the public mind, whether the traits are fair attributions or not. But comedians cannot simply create these out of whole cloth; we must not forget news coverage along with the party and candidate attempts at self-definition or opponentcharacterization. These provide the raw material through political rhetoric, public appearances, and televised advertising. The most a comedian can do is to pick out comedically promising traits and test them against audience perceptions. The "political dispositions" of comedians and their writers cannot override comedic necessities. A caricature that places a big nose on the face of a man who does not have one will not succeed.

48 Every joke a stand-up comic tells amounts to a referendum on its premise. The comedian offers the audience a proposition: Al Gore is stiff, Dan Quayle is dumb, Bob Dole is ancient. The audience either validates it by laughing or rejects it by remaining silent. There's no need to calculate margins of error for a survey or wait for the upstate returns. Telling the people what they want to hear 
is a temptation for the politician, but a necessity for the comedian.

\section{Info-tainment}

49 Regardless of what the Pew numbers suggest, the consensusseeking imperative of stand-up comedy suggests that the possibilities of learning anything new from late-night monologues are limited. Consider this Conan O'Brien joke, from the 1996 Clinton-Dole race:

Bob Dole, believe it or not, took a lap around the Charlotte Motor Speedway. ... You could tell it was Dole because he had his blinker on the whole time. ${ }^{37}$

It seems unlikely that Dole's lap around the Charlotte Speedway was a matter of common knowledge, so you could assume that the audience indeed "learned" that fact from O'Brien's monologue. But this is not the bit of information upon which the punchline turns. To "get" this joke, audience members did not need prior knowledge of Dole's racing escapade. They would, however, need to know - or believe - a few things prior to hearing the joke:

1. Speedways are similar to highways in that cars are driven on them, but dissimilar in that they are used for racing.

2. Old people, according to a well-established comic stereotype, often drive down the highway unaware that they have left a turn signal blinking.

\section{Bob Dole is old.}

As this example indicates, joke set-ups can convey new information, but that new information must be related to something the audience already knows or believes in order for the joke to "work." To put it another way, although a joke may trade on both new information (Dole's lap around the speedway) and matters of prior knowledge or belief (Dole is old), the joke-relevant information is necessarily a matter of prior knowledge.

50 Here is a two-part example, involving a different politician, from David Letterman's monologue of September 17, 1996:

Al Gore was in New York City today; and it was a wonderful trip, very successful, thanks only to some heads-up work by the Secret Service. Because of their 
great work, Gore was only mistaken three times by dogs for trees.

Then later in the day [Gore] went up to Grant's tomb. He took a tour to Grant's tomb. I think this was smart. While he was touring Grant's tomb, Al Gore wore a button that read, "just visiting." I think that was an excellent idea. ${ }^{38}$

J ust as Dole's Charlotte trip is likely to be "news" to much of O'Brien's audience, Letterman viewers might be hearing of Gore's New York visit for the first time when they hear these jokes. In fact, there are two bits of new information here, parceled out over two set-ups: (1) Gore visited New York City today, and (2) he went to Grant's tomb. But the joke-relevant information crucial for both is the same, and it is a matter of prior audience knowledge: "Gore = stiff," just as “Dole =old."

51 Stand-up comedy is an extremely austere form of communication. This is particularly true of the variety practiced by late-night hosts in the Carson mold, which is almost Kabuki-like in its formal rigidity. Factor in the strictures of commercial television, including the imperative to maintain "nonpartisan" balance; and the scope of late-night comedy's influence is, at best, severely circumscribed. While it may reinforce anti-political cynicism, however, it can hardly be accused of inventing this attitude, which has been a salient feature of the American ethos since Artemus Ward was a pup. Like this Civil War progenitor, the late-night comics communicate a covert contempt for the notion of representative democracy's viability. This sentiment might disturb the audience, were it not for the cheerful way in which it is delivered.

\section{Make Room for Satire?}

52 As if in response to the Pew poll, the Annenberg Public Policy Center conducted a survey in 2004 that found the late-night comedy audience to be better-informed than those who rely on cable reports, network newscasts, or even daily newspapers as their primary sources of information. Again there is no reason to believe these audiences are mutually exclusive, but the Annenberg results do call into question the usurper notion that the public's information needs are necessarily ill-served by topical comedy. 
53 The smartest group, as determined by a current-events quiz, were regular viewers of The Daily Show with J on Stewart. ${ }^{39}$ This should come as no surprise to those who watch the show. Stewart and company take full advantage of comedy's imperative to make judgments and draw conclusions. To cite one example, when Dick Cheney told MSNBC's Gloria Borger that he had "never said" that the connection between Saddam Hussein's government and al Qaeda had been "pretty well confirmed" it was left to the fake-news organization to roll the tape of Cheney saying exactly that. ${ }^{\mathbf{4 0}}$

54 Because it does not shrink from passing judgment, The Daily Show can go beyond journalism in satisfying the audience thirst for "truth" - or conclusions, at least. It also has important advantages over traditional late-night shows in the network mode. First is its format: the news-parody genre, unlike stand-up, allows for lengthy and complex setups. Stewart can, and often does, introduce substantive new information at some length, enabling him to use it in a "joke-relevant" way, as with the Cheney episode. The second advantage is a by-product of "narrowcasting" on cable TV. Co-executive producer Ben Karlin has said that The Daily Show has a "boutique" audience - averaging around a million viewers - by contrast with department-store audience for Leno at six million and Letterman at a little under five million. ${ }^{41}$ Freed from the legacy of broadcasting's "lowest common denominator" paradigm, The Daily Show can afford to flirt with complexity. The restraints of "objectivity" are similarly loosened: Stewart seems to worry less than Leno about "losing half the crowd," since he starts with far less than half of Leno's overall number.

55 Perhaps The Daily Show is at the vanguard of a new wave of politically engaged comedy. I think we need it. The boat has tipped, but our political leaders are back on shore, high and dry. We're the ones who have to sink or swim. Laughter can't save us; but if engaged and outraged rather than safe and cynical, it might keep us afloat long enough for us to rescue ourselves.

(c) Russell L. Peterson, 2005.

\section{Notes}

1 Garry Wills, A Necessary Evil: A History of American Distrust of Government, New York, Simon and Schuster, 1999.

2 Charles E. Schutz, Political Humor: From Aristophanes to 
Sam Ervin, London, Associated University Press, 1977. Louis D. Rubin defines the gap between real and ideal at the heart of his "joke." "On the one hand," he writes, "there are the ideals of freedom, equality, self-government. ... On the other hand there is the Congressional Record." But he does not consider this attitude to be a cynical dead end, noting that, "In a democracy, the capacity for self-criticism would seem to be an essential function of the body politic, and surely this has been one of the chief tasks of the American writer" ("The Great American J oke," What's So Funny? Humor in American Culture, Nancy A. Walker, ed., Wilmington, DE, Scholarly Resources, 1998, pp. 107-132, on pp. 109-110).

3 Quoted in E. B. White and Katherine S. White, eds., A Subtreasury of American Humor, New York, Coward-MoCann, 1941, p. xxii.

4 Inasmuch as these opinion leaders often receive their talking points from political operatives, there is reason to suspect that late-night's framing of political topics is subject to deliberate manipulation, at least at some remove. Late-night does not constitute a discrete channel within the larger media universe: it is part of the "echo chamber."

5 Sonia Orwell and Ian Angus, eds., "Funny, but not Vulgar," The Collected Essays, J ournalism and Letters of George Orwell: As I Please, 1943-1945, Volume III, New York: Harcourt, Brace and World, 1968, p. 284.

6 J ohn Limon, Stand-up Comedy in Theory, or, Abjection in America, Durham, NC, Duke University Press, 2000, p. 4.

7 David Marc, Comic Visions: Television Comedy and American Culture, Boston, Unwin Hyman, 1989, p. 17.

8 "The talk show host is as much a representative of the people as an elected official" (Bernard Timberg, "Television Talk and Ritual Space: Carson and Letterman," Southern Speech Communication J ournal, 52, 3, Summer, 1987, pp. 390-402, on p. 402).

9 Ibid., p. 390.

$10 \quad$ Ibid., p. 392.

11 Kenneth Tynan, "Fifteen Years of the Salto Mortale," Life Stories: Profiles from The New Yorker, David Remnick, ed., New 
York, Modern Library, 2001, pp. 310-354, on p. 319.

12 Constance Rourke, American Humor: A Study of the National Character, Tallahassee, University Press of Florida, 1986, p. 11.

13 Marshall Sella, "The Stiff Guy vs. the Dumb Guy," New York Times Magazine, September 24, 2000, pp. 72-80+, on p. 102.

14 The Tonight Show with J ay Leno, NBC, September 25, 2001.

15 David Herbert Donald, Lincoln, New York, Touchstone, 1996, p. 374.

16 Ibid., p. 543.

17 James C. Austin, Petroleum V. Nasby, New York, Twayne, 1965, p. 7.

18 Petroleum V. Nasby [David Ross Locke], "The Assassination," The Assault of Laughter: A Treasury of American Political Humor, Arthur P. Dudden, ed., New York, Thomas Yoseloff, 1962, pp. 132-134, on p. 132.

19 Quoted in Austin, Nasby, p. 44.

20 J ames C. Austin, Artemus Ward, New York, Twayne, 1964, p. 7.

21 Carson came close to showing his hand in explaining the rationale behind the Turbo character to TV Guide: 'What you're doing is showing the stupidity of that particular view so that you can make your point comedically. If he's for handguns and wants everybody to arm themselves, it's obvious to anybody who's watching, the point we're trying to make" (quoted in Stephen Cox, Here's J ohnny: Thirty Years of America's Favorite Late Night Entertainment, New York, Harmony Books, 1992, p. 174).

22 Quoted in Walter Blair, Native American Humor, New York, Harper and Row, 1960, p. 401.

23 Austin, Artemus Ward, p. 7.

24 Austin traces Browne's vaguely-defined and shifting sympathies in Artemus Ward.

25 Artemus Ward [Charles Farrar Browne], "Interview with 
President Lincoln," The Assault of Laughter, pp. 94-99, on p. 98.

26 Artemus Ward [Charles Farrar Browne], "The Show is

Confiscated," The Assault of Laughter, pp. 99-104, on p. 103.

27 Henri Bergson, Laughter: An Essay on the Meaning of the Comic, Cloudesley Brereton and Fred Rothwell, trs., Los Angeles, Green Integer Books, 1999, p. 11.

28 Ibid., p. 145.

29 Ibid., p. 147.

30 Sella, "The Stiff Guy vs. the Dumb Guy," p. 77.

31 Ibid., pp. 72-73.

32 Ibid., p. 73.

33 Quoted in J ames Bennet, "Did You Hear the One About the '96 Campaign?" New York Times, July 9, 1996, p. A17.

34 Sella, p. 78.

35 See Richard Hofstadter, Anti-Intellectualism in American Life, New York, Random House, 1962.

36 Ibid.

37 Quoted in Bennett, "Did You Hear the One About the '96 Campaign?"

38 Late Show with David Letterman. CBS, September 17, 1996.

39 National Annenberg Election Survey, NAES04, September 21, 2004, http:/ www.annenbergpublicpolicy center.org.

40 Frank Rich, "Happy Talk News Covers a War," The New York Times, J uly 18, 2004, http:/ / 80-web. lexisnexis.com.proxy.lib.uiowa.edu/ universe.

41 Quoted in Paul Farhi, "Take Iraq. Please: For Letterman, Leno and Company, the Mideast Is a Comedy Winner," Washington Post, March 13, 2003, p. C1, http:// 80-web. lexisnexis. com. proxy. lib. uiowa. edu / universe. On a similar note, Karlin explained to the Boston Globe, "You have a different charge when you're J ay Leno" (quoted in Matthew Gilbert, "On TV: On 
Topic of War, Most Late-Night Hosts Tread Lightly," Boston Globe, March 13, 2003, p. D1, http:// 80-web.lexisnexis.com.proxy.lib.uiowa.edu/ universe). 